\title{
Autophagy is involved in anticancer effects of matrine on SGC-7901 human gastric cancer cells
}

\author{
JUNQIANG ZHANG ${ }^{1,2}$, YUMIN LI ${ }^{1,2}$, XIAOHUI CHEN ${ }^{3}$, TAO LIU ${ }^{1,2}$, \\ YINGTAI CHEN ${ }^{1,2}$, WENTING HE ${ }^{4}$, QUANBAO ZHANG ${ }^{4}$ and SHIYUAN LIU ${ }^{1,2}$ \\ ${ }^{1}$ The Second Hospital of Lanzhou University, Lanzhou 730030; ${ }^{2}$ Gansu Provincial Key Laboratory \\ of Digestive System Tumors, Lanzhou 730030; ${ }^{3}$ Gansu Provincial People's Hospital, Lanzhou \\ 730000; ${ }^{4}$ The First Hospital of Lanzhou University, Lanzhou 730000, P.R. China
}

Received December 22, 2010; Accepted February 15, 2011

DOI: $10.3892 / o r .2011 .1277$

\begin{abstract}
Matrine has a wide range of pharmacological effects including antitumor activity in vitro and in vivo. Autophagy is closely associated with tumors and plays an important role in human tumor suppression, so inducing autophagy is a potential therapeutic strategy in adjuvant chemotherapy. The aim of this study was to investigate whether or not autophagy is involved in antitumor effects of matrine on human gastric cancer SGC-7901 cells, and to further elucidate the underlying molecular mechanisms. Sulphorhodamine B (SRB) assay was used to examine matrine's cytotoxicity against SGC-7901 gastric cancer cells. The effects of matrine on the cell cycle and apoptosis were measured by flow cytometry, and cellular morphology was observed under an inverted phase contrast microscope and transmission electron microscope. Monodansylcadaverine (MDC) staining was used to detect autophagy. The expression levels of Bax and Beclin 1 in SGC-7901 cells were monitored by real-time quantitative reverse transcription-polymerase chain reaction (RT-PCR). The results showed that matrine significantly inhibited the proliferation of SGC-7901 gastric cancer cells and induced G1-phase cell cycle arrest. Furthermore, both autophagy and apoptosis were activated during the matrine-induced death of SGC-7901 cells. Beclin 1 is involved in matrine-induced autophagy and the pro-apoptotic mechanisms of matrine may be associated with its up-regulation of Bax expression. These findings indicate that matrine is a potent antitumor agent for treating gastric cancer. The ability of matrine to induce autophagy underlines its potential utility as a new gastric cancer treatment modality.
\end{abstract}

Correspondence to: Professor Yumin Li, Gansu Provincial Key Laboratory of Digestive System Tumors, The Second Hospital of Lanzhou University, 82 Cuiyingmen, Lanzhou, Gansu Province, P.R. China

E-mail: liym@1zu.edu.cn

Key words: matrine, autophagy, gastric cancer, Bax, Beclin 1

\section{Introduction}

Gastric cancer is a major public health burden. Although its incidence and mortality have fallen dramatically in most countries over the past 70 years, gastric cancer remains the fourth most common cancer and the second leading cause of cancer-related death in the world. There were an estimated 934,000 new diagnoses and 700,000 deaths from gastric cancer worldwide per year in 2002 (1). Almost two-thirds of the cases occur in developing countries and $42 \%$ in China alone (1). The age-standardized incidence rates were 22.0 and 10.3 per 100,000 per annum in males and females, respectively, with corresponding mortality rates being 14.3 and 8.3 per $100,000(2,3)$. The geographical distribution of gastric cancer is characterized by wide international variations. Generally, incidence rates are highest in Eastern Asia (China, and Japan), Eastern Europe and South America and lowest in Southern Asia, North and East Africa, North America, Australia and New Zealand (1). Prognosis of gastric cancer is generally rather poor, with 5-year relative survival below $30 \%$ in most countries (4). Current major treatment modalities for gastric cancer comprise surgery and chemotherapy. Surgical resection is the mainstay of treatment and can cure patients with early-stage cancer. Unfortunately, gastric cancer at an early stage may be clinically silent and, in most countries, patients are diagnosed at an advanced stage when the tumor is irresectable or metastatic. For these patients, as well as in cases with disease recurrence after initial surgical treatment, systemic chemotherapy is the main treatment option because it prolongs survival without quality of life compromise (5). The existing chemotherapeutic drugs, however, do not have ideal curative effects and meanwhile have many undesirable side effects. Consequently, development of pharmacologically effective agents with little toxicity or few side effects from natural products has become a new urgent research goal.

Matrine is a quinolizidine alkaloid extracted from Sophora flavescens Ait, Sophora subprostrata or Sophora alopecuroides in traditional Chinese medicine, with a molecular formula of $\mathrm{C}_{15} \mathrm{H}_{24} \mathrm{~N}_{2} \mathrm{O}$ (Fig. 1). Matrine has been widely used in treatment of viral hepatitis, hepatic fibrosis, cardiac arrhythmia and skin diseases, such as atopic dermatitis and 


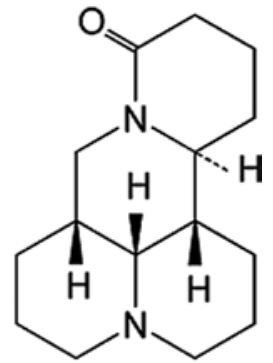

Figure 1. Chemical structure of matrine with a molecular formula of $\mathrm{C}_{15} \mathrm{H}_{24} \mathrm{~N}_{2} \mathrm{O}$ and a molecular weight of $248.37 \mathrm{Da}$.

eczema in China, because it has a wide range of pharmacological effects in vitro and in vivo, such as anti-inflammatory (6-9), antiviral (10-12), antifibrotic $(13,14)$, analgesic $(15)$, antiarrhythmic $(16,17)$, positive inotropic effect $(18)$ and hepatoprotective effect (19). Recent evidence indicated that matrine may also play an important role in the treatment of tumors. Both in vivo and in vitro studies showed that matrine inhibits the proliferation of tumor cells (20-28). Matrine could induce apoptosis in leukemia U937 and K562 cells (29,30), gastric cancer MKN45 and SGC-7901 cells $(23,25)$, C6 glioma cells (26), multiple myeloma cells (27), and hepatocellular carcinoma H22 cells (28). Matrine can also inhibit invasiveness and metastasis of human malignant melanoma cell line A375 and cervical cancer HeLa cells $(31,32)$, and induce differentiation of leukemia K562 cells (20). Furthermore, matrine attenuated cancer cachexia-related symptoms in colon 26 tumor-bearing mice probably through inhibiting the production of pro-inflammatory cytokines (33). In addition, it has been reported that matrine activated autophagy in rat C6 glioma cells (26). Accumulating studies have demonstrated that autophagy is closely associated with tumors and plays an important role in human tumor suppression (34-36). Autophagy has also been observed in tumor cell lines treated with diverse chemotherapeutic drugs. Many of the agents can directly lead the cancer cell to autophagic cell death, called type II programmed cell death (PCD). For example, 5-fluorouracil induces autophagic cell death of Bax or PUMA deficient human colon cancer cells (37). The above results suggest that autophagy is a potential therapeutic target in adjuvant chemotherapy, especially induction of autophagic cell death may provide leverage to treat cancer that is chemoresistant on the basis of ineffective apoptosis. Therefore, we designed this study to investigate whether or not autophagy is involved in antitumor effects of matrine on human gastric cancer SGC-7901 cells, and to further elucidate the molecular mechanisms underlying autophagy and apoptosis induced by matrine.

\section{Materials and methods}

Reagents. Fetal bovine serum was purchased from Sijiqing Biological Engineering Company Limited (Hangzhou, China). Sulphorhodamine B (SRB), propidium iodide (PI), L-glutamine, Annexin V-FITC apoptosis detection kit, and monodansylcadaverine (MDC) were obtained from
Sigma-Aldrich (St. Louis, MO, USA). RPMI medium 1640 and TRIzol reagent were bought from Invitrogen (Carlsbad, CA, USA). Primescript ${ }^{\mathrm{TM}}$ reverse transcription (RT) reagent kit and SYBR ${ }^{\circledR}$ Premix Ex Taq ${ }^{\mathrm{TM}}$ II were purchased from Takara (Dalian, China). Matrine was purchased from Xi'an Tianyuan Biologics Plant (Xi'an, China), with a purity of over 99\% as proved by high-performance liquid chromatography. Matrine was dissolved in sterile double distilled water at a stock concentration of $40 \mathrm{mg} / \mathrm{ml}$, stored at $-20^{\circ} \mathrm{C}$ in the dark, and then diluted in RPMI-1640 medium to obtain the desired concentration.

Cell culture. Gastric cancer SGC-7901 cell line was obtained from Shanghai Institute of Cell Biology, Chinese Academy of Sciences (Shanghai, China). The cells were maintained in RPMI-1640 medium supplemented with $10 \%$ fetal bovine serum, $100 \mathrm{U} / \mathrm{ml}$ of penicillin and $100 \mu \mathrm{g} / \mathrm{ml}$ of streptomycin at $37^{\circ} \mathrm{C}$ in a $5 \% \mathrm{CO}_{2}$ incubator. The cells in mid-log phase were used in experiments.

Sulphorhodamine B colorimetric assay for cell proliferation. The sulphorhodamine B (SRB) colorimetric assay was used for determining the inhibition of matrine against SGC-7901 cells, which estimates cell number indirectly by staining total cellular protein with the dye SRB (38). The cells were seeded in 96-well flat bottom microtiter plates (Costar 3599, Corning Inc., Corning, NY) at a density of $5 \times 10^{3}$ cells per well, allowed to adhere in $5 \% \mathrm{CO}_{2}$ incubator at $37^{\circ} \mathrm{C}$. After $24 \mathrm{~h}$ incubation, matrine at various concentrations $(0,0.25$, $0.5,1.0,2.0 \mathrm{mg} / \mathrm{ml}$ ) was added to each well and then the cells were further incubated for 24 and 72 h, respectively. Each concentration of matrine was repeated in six wells in the same plate. At the end of each exposure time, the cells were fixed with $10 \%(\mathrm{w} / \mathrm{v})$ trichloroacetic acid (TCA) at $4^{\circ} \mathrm{C}$ for $1 \mathrm{~h}$, and then stained at room temperature for $20 \mathrm{~min}$ with $0.4 \%(\mathrm{w} / \mathrm{v})$ SRB solution. Cells were subsequently washed with $1 \%$ acetic acid five times and dissolved in $150 \mu \mathrm{l}$ of $10 \mathrm{mmol} / 1$ Tris base solution ( $\mathrm{pH}$ 10.5). The absorbance value per well at $510 \mathrm{~nm}$ was read using an automatic multiwell spectrophotometer (PowerWave X, Bio-Tek Instruments Inc., USA). All SRB assays were repeated three times. The inhibitory rate of cellular proliferation was calculated according to the formula: (1 - experimental OD value/control OD value) $\times 100 \%$.

Cell cycle analysis by flow cytometry. Flow cytometry was used to assess DNA content as a surrogate measure for cell cycle phases. SGC-7901 cells were treated with matrine at final concentration of $0,0.25,0.5$ and $1.0 \mathrm{mg} / \mathrm{ml}$, respectively, for $24 \mathrm{~h}$. At the end of the treatment period, both floating and attached cells were collected and centrifuged before washed with cold phosphate-buffered saline (PBS), and then fixed in $70 \%$ cold ethanol overnight at $4^{\circ} \mathrm{C}$. Fixed cells were washed twice with PBS to remove trace ethanol, resuspended in fluorochrome solution containing $50 \mu \mathrm{g} / \mathrm{ml} \mathrm{PI}, 3.4 \mathrm{mmol} / \mathrm{l}$ sodium citration, $20 \mu \mathrm{g} / \mathrm{ml}$ RNase A and $1 \%$ Triton X-100 and then incubated in the dark at room temperature for 30 min. Cell cycle analysis was performed using an EPICS XL flow cytometer (Beckman Coulter, CA, USA). All experiments were performed in triplicate. Results are presented as $\%$ of cells in a particular phase. 
Evaluation of cell apoptosis. The transversion of phosphatidylserine from the inner to outer plasma membrane leaflet, an initial event in the apoptotic pathway, was assessed by dual dye staining using Annexin V-FITC/PI (39). SGC-7901 cells were exposed to matrine at the concentration of $0,0.5$, 1.0 and $2.0 \mathrm{mg} / \mathrm{ml}$, respectively. After $24 \mathrm{~h}$ of treatment, cells were harvested, washed with cold PBS, and resuspended in Annexin-V binding buffer. Annexin V-FITC (5 $\mu \mathrm{l})$ and $10 \mu \mathrm{l}$ of PI were added and incubated with the cells for $10 \mathrm{~min}$ at room temperature in the dark, followed by cytometric analysis (EPICS XL, Beckman Coulter) to distinguish between viable, early apoptotic, late apoptotic or necrotic cells. The apoptotic rate was calculated as the percentage of early apoptotic cells plus the percentage of late apoptotic cells. All experiments were performed in triplicate.

Observation of morphological changes. SGC-7901 cells were equally seeded in 24-well plates (Costar 3524, Corning Inc.) and then treated with matrine at the concentration of $0,0.25$, $0.5,1.0$ and $2.0 \mathrm{mg} / \mathrm{ml}$, respectively. After $24 \mathrm{~h}$ of treatment, the morphology of SGC-7901 cells was observed under an inverted phase contrast microscope (Olympus, Tokyo, Japan).

Transmission electron microscopic examination. After $24 \mathrm{~h}$ of treatment, SGC-7901 cells were harvested by trypsinization, washed twice with PBS and fixed with $2.5 \%$ glutaraldehyde in $0.1 \mathrm{~mol} / \mathrm{l} \mathrm{PBS}$ ( $\mathrm{pH} \mathrm{7.4)}$ for $90 \mathrm{~min}$ at room temperature, and post-fixed in $1 \%$ osmium tetraoxide for $30 \mathrm{~min}$. After washing with PBS, the cells were progressively dehydrated in a $10 \%$ graded series of $50-100 \%$ ethanol and propylene oxide, and embedded in Epon 812 resin. The blocks were cut into ultrathin sections with a microtome, which were then stained with saturated uranyl acetate and lead citrate. The ultrastructure of the cells was then observed under a transmission electron microscope (JEM-1230, JEOL, Japan).

Visualization of MDC-labeled autophagic vacuoles. MDC staining of autophagic vacuoles was performed for autophagy analysis as previously described (40). SGC-7901 cells growing on coverslips were treated with matrine for $48 \mathrm{~h}$. After treatments, the cells were stained with $0.05 \mathrm{mM}$ MDC in $\mathrm{PBS}$ at $37^{\circ} \mathrm{C}$ for $10 \mathrm{~min}$, and then washed three times with PBS to remove excess MDC and immediately analyzed under a fluorescence microscope (IX-81; Olympus, Japan). Fluorescence of MDC was measured at the excitation wavelength $380 \mathrm{~nm}$ with an emission filter at $530 \mathrm{~nm}$.

Real-time quantitative RT-polymerase chain reaction. SGC-7901 cells were cultured in $35-\mathrm{mm}$ dishes and then collected after treatment with matrine for $24 \mathrm{~h}$. Total RNA was isolated from cells using TRIzol reagent according to the manufacturer's protocol. RNA concentration and purity were measured with a spectrophotometer at A260 and A260/280, respectively. RNA was reverse-transcribed into cDNA using a Primescript ${ }^{\mathrm{TM}}$ RT reagent kit according to the manufacturer's instructions. Real-time quantitative polymerase chain reaction (PCR) was carried out with the SYBR-Green I fluorescent dye method and a Rotor Gene 3000 real-time PCR apparatus (Corbett Research Company,

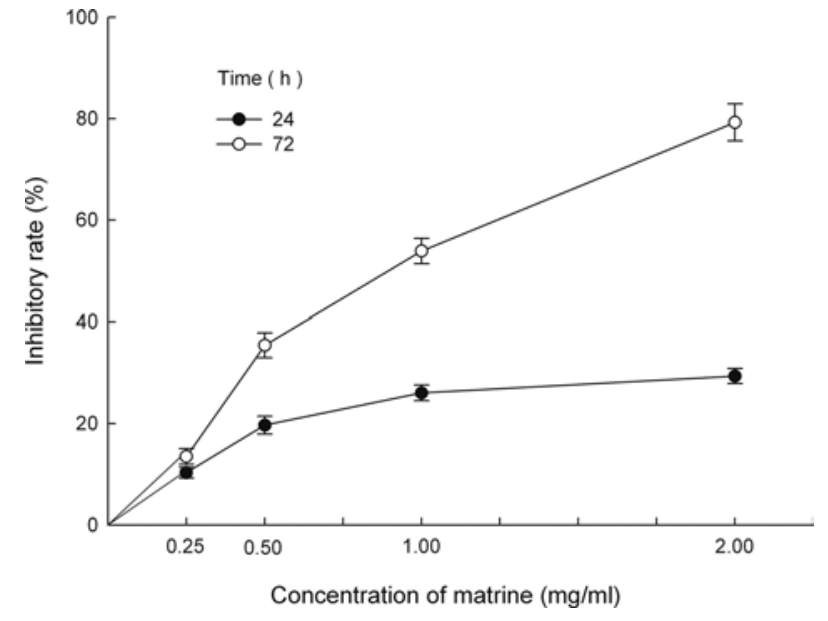

Figure 2. Growth inhibiting effects of matrine on SGC-7901 cells was determined by Sulphorhodamine B (SRB) assay. SGC-7901 cells were treated with matrine at the concentration of $0.25,0.5,1.0$ and $2.0 \mathrm{mg} / \mathrm{ml}$ for 24 and $72 \mathrm{~h}$, respectively. Matrine inhibited the growth of SGC-7901 cells in a dose- and time-dependent manner. $n=3$; Mean \pm SD.

Australia). The sequences of primers used are as follows: i) for Bax, forward, 5'-TGCTTCAGGGTTTCATCCAG-3' and reverse, 5'-GGCGGCAATCATCCTCTG-3'; ii) for Beclin 1, forward, 5'-GAGGGATGGAAGGGTCTAAG-3' and reverse, 5'-GCCTGGGCTGTGGTAAGT-3'; iii) for $\beta$-actin, forward, 5'-TGGCACCCAGCACAATGAA-3' and reverse, 5'-CTAAGTCATAGTCCGCCTAGAAGCA-3'. $\beta$-actin was used as an internal control to evaluate the relative expressions of Bax and Beclin 1. The PCR conditions were as follows: a pre-denaturing at $95^{\circ} \mathrm{C}$ for $2 \mathrm{~min}$, followed by 45 cycles of denaturation at $95^{\circ} \mathrm{C}$ for $10 \mathrm{sec}$, annealing/extension at $60^{\circ} \mathrm{C}$ for $20 \mathrm{sec}$. The amplification specificity was checked by melting curve analysis. The PCR products were visualized by gel electrophoresis to confirm the presence of a single product with a correct size. The $2^{-\Delta \Delta C T}$ method was used to calculate the relative abundance of target gene expression generated by Rotor-Gene Real-Time Analysis Software 6.1.81. For each cDNA, the target gene mRNA level was normalized to $\beta$-actin mRNA level. Results were expressed as the ratio of normalized target gene mRNA level in cells treated with matrine to that in cells not treated with matrine. The experiments were performed in triplicate.

Statistical analysis. The data are expressed as the mean \pm SD. Statistical analysis was performed using the SPSS 16.0 for Window. One-way analysis of variance (ANOVA) was used to analyze statistical differences between groups under different conditions. $\mathrm{P}<0.05$ was considered statistically significant.

\section{Results}

Effects of matrine on growth inhibition of SGC-7901 cells. The cytotoxicity of matrine on the proliferation of SGC-7901 cells was examined by SRB assay. As shown in Fig. 2, matrine inhibited the proliferation of SGC-7901 cells in a dose- and time-dependent manner. After $24 \mathrm{~h}$ of treatment with $1.0 \mathrm{mg} / \mathrm{ml}$ matrine, the inhibitory rate on growth of SGC-7901 cells was $26.04 \pm 1.55 \%$, and when the incubation 


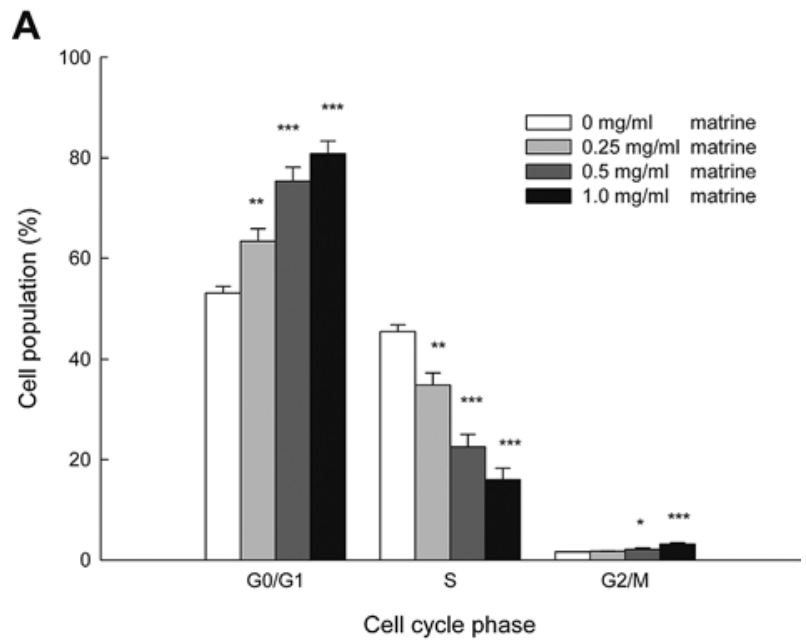

C

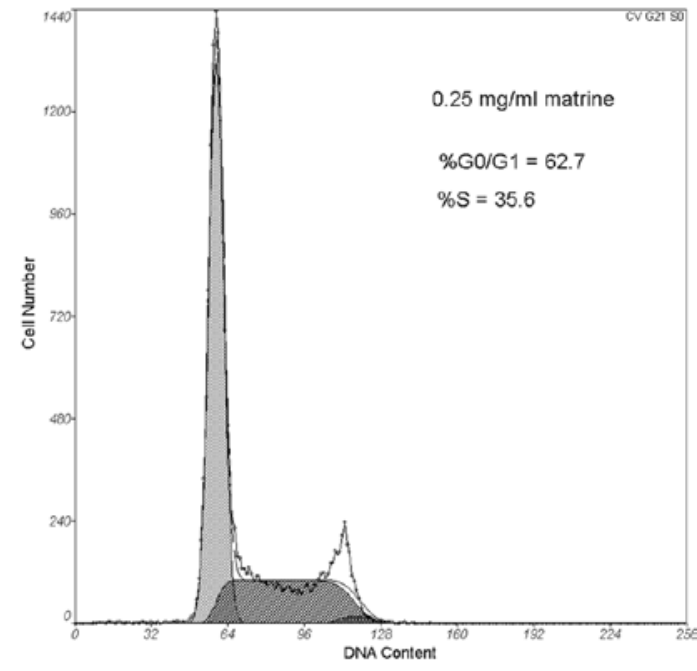

$\mathrm{E}$

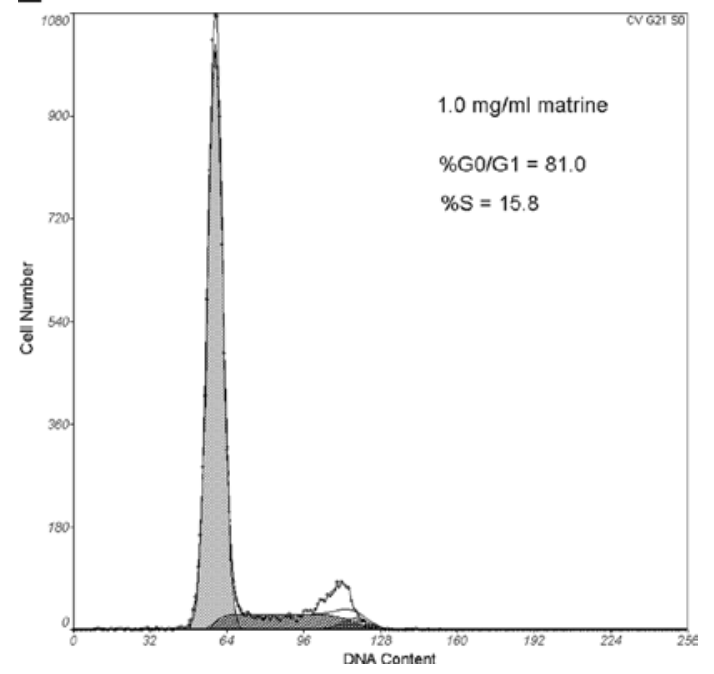

B

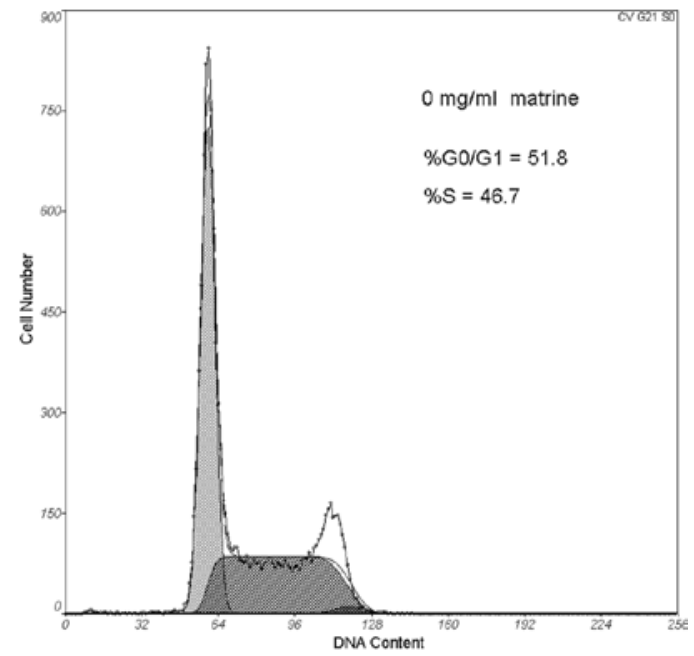

D

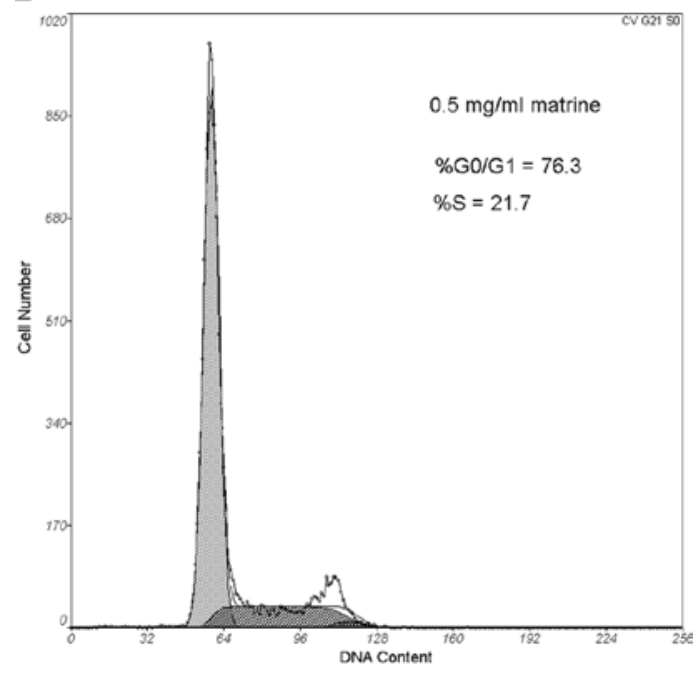

Figure 3. Effect of matrine on cell cycle distribution in SGC-7901 cells. (A) Matrine treatment induced a dose-dependent increase in the proportion of cells in G0/G1 phase while causing a decrease in the percentage of cells in the $\mathrm{S}$ phase compared to control. Results are expressed as mean $\pm \mathrm{SD}$ $(\mathrm{n}=3) .{ }^{*} \mathrm{P}<0.05,{ }^{* *} \mathrm{P}<0.01,{ }^{* * *} \mathrm{P}<0.001$ compared with control group. (B-D) Representative histograms are from SGC-7901 cells incubated with different concentrations $(0,0.25,0.5,1.0 \mathrm{mg} / \mathrm{ml})$ of matrine.

time was prolonged to $72 \mathrm{~h}$, the inhibitory rate increased to $53.88 \pm 2.49 \%$. At the concentration of $2.0 \mathrm{mg} / \mathrm{ml}$ matrine, the inhibitory ratio reached $79.25 \pm 3.64 \%$ after $72 \mathrm{~h}$ of treatment.

Matrine arrests SGC-7901 cells in G1-phase of cell cycle. One common mechanism for the antiproliferative effect of anti- cancer drugs is through retardation of cell cycle progression. To explore the possible mechanism underlying the inhibitory effect of matrine on growth of SGC-7901 cells, cell cycle distribution was analyzed by flow cytometry. As shown in Fig. 3, treatment with matrine induced a dose-dependent increase in the number of SGC-7901 cells in the G0/G1 

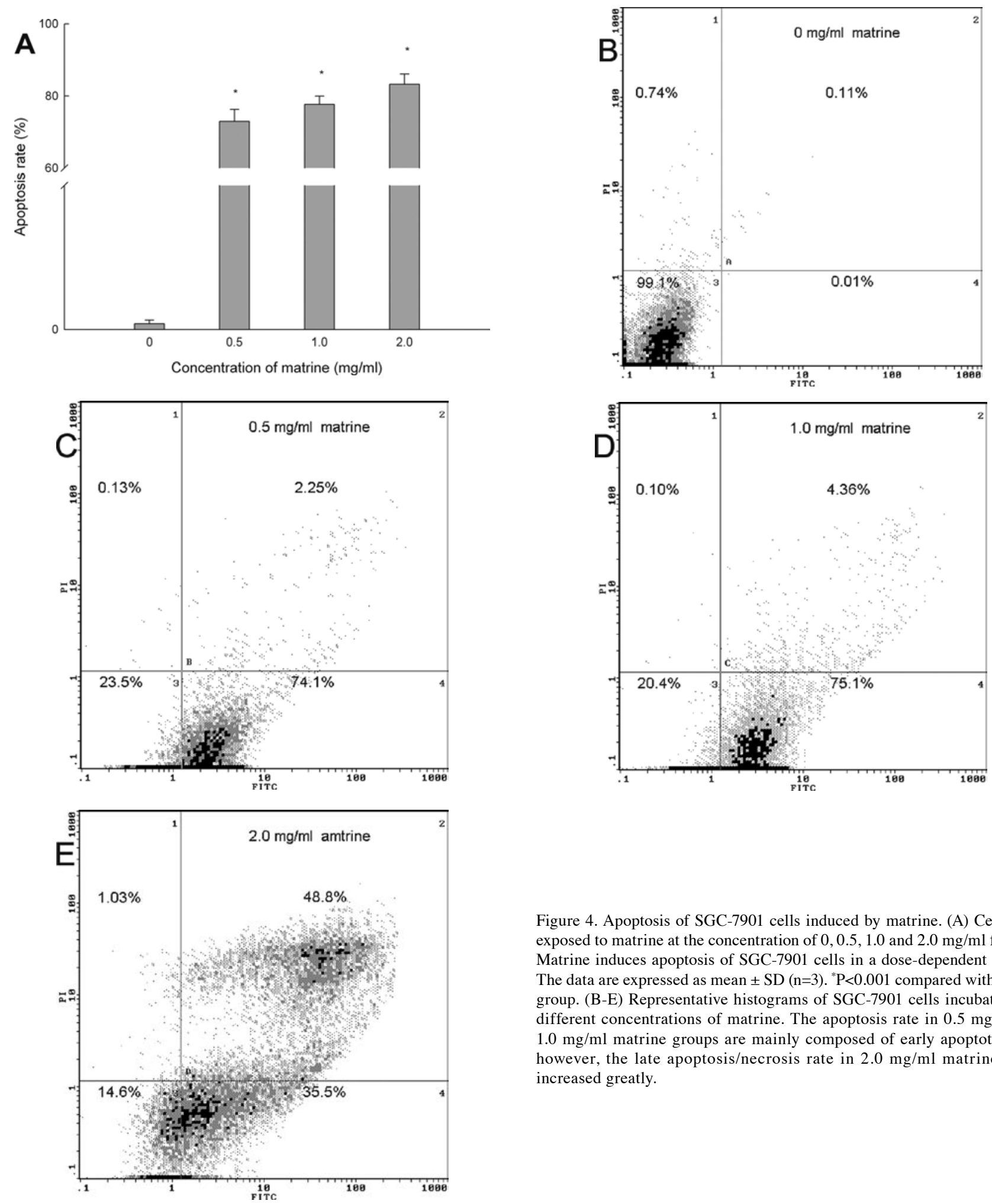

phase while causing marked decrease in the proportion of cells in the $\mathrm{S}$ phase, indicating that the $\mathrm{G} 0 / \mathrm{G} 1$ phase cell cycle arrest may be associated with matrine-mediated SGC-7901 cell growth inhibition in a dose-dependent manner.

Matrine induces apoptosis in SGC-7901 cells. As shown in Fig. 4A, after treatment with matrine at the concentration of $0,0.5,1.0$ and $2.0 \mathrm{mg} / \mathrm{ml}$ for $24 \mathrm{~h}$, the apoptosis rate of SGC-7901 cells was $0.20 \pm 0.13 \%, 72.92 \pm 3.41 \%, 77.75 \pm 2.19 \%$,

$83.28 \pm 2.75 \%$, respectively. That is to say, matrine induced apoptosis of SGC-7901 cells in a dose-dependent manner. The representative histograms of flow cytometry displayed that the early apoptosis rate was $0.01 \%$ in SGC-7901 cells not treated with matrine, and was $74.10,75.10$, and $35.50 \%$, respectively, in SGC-7901 cells treated with matrine at the concentration of $0.5,1.0$ and $2.0 \mathrm{mg} / \mathrm{ml}$ (Fig. 4B-E). Although early apoptosis rate in $2.0 \mathrm{mg} / \mathrm{ml}$ matrine group decreased compared with $1.0 \mathrm{mg} / \mathrm{ml}$ matrine group, the late apoptosis/

Figure 4. Apoptosis of SGC-7901 cells induced by matrine. (A) Cells were exposed to matrine at the concentration of $0,0.5,1.0$ and $2.0 \mathrm{mg} / \mathrm{ml}$ for $24 \mathrm{~h}$. The data are expressed as mean $\pm \mathrm{SD}(\mathrm{n}=3)$. ${ }^{*} \mathrm{P}<0.001$ compared with control group. (B-E) Representative histograms of SGC-7901 cells incubated with different concentrations of matrine. The apoptosis rate in $0.5 \mathrm{mg} / \mathrm{ml}$ and $1.0 \mathrm{mg} / \mathrm{ml}$ matrine groups are mainly composed of early apoptotic cells however, the late apoptosis/necrosis rate in $2.0 \mathrm{mg} / \mathrm{ml}$ matrine group increased greatly. 

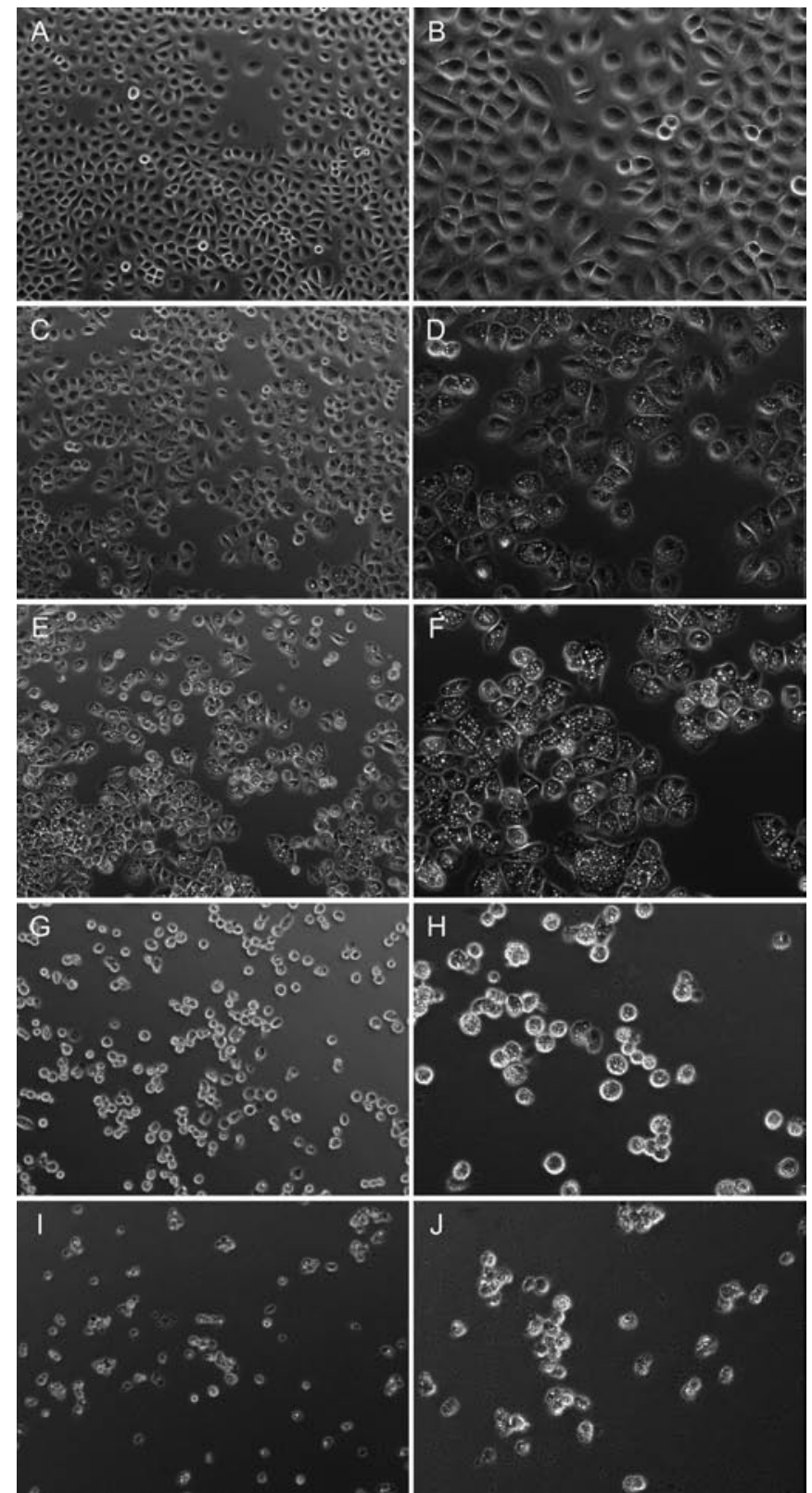

Figure 5. Matrine-induced morphologic changes of SGC-7901 by inverted phase contrast microscopy. The untreated control cells adhere well, displaying normal morphology of SGC-7901 cells. In contrast, abundant cytoplasmic vacuoles were observed in cells treated with matrine. Moreover, vacuolization in cytoplasm progressively became larger and denser with increasing concentration of matrine. The majority of cells in $1.0 \mathrm{mg} / \mathrm{ml}$ matrine group became round and shrunken, especially in $2.0 \mathrm{mg} / \mathrm{ml}$ matrine group, and could not be affixed to the wall or suspended in culture medium. $(\mathrm{A}, \mathrm{C}, \mathrm{E}, \mathrm{G}$ and $\mathrm{I}) \times 100$ magnification, $(\mathrm{B}, \mathrm{D}, \mathrm{F}, \mathrm{H}$ and $\mathrm{J}) \times 200$ magnification. (A and B), $0 \mathrm{mg} / \mathrm{ml}$ matrine; $(\mathrm{C}$ and $\mathrm{D}), 0.25 \mathrm{mg} / \mathrm{ml}$ matrine; ( $\mathrm{E}$ and F), $0.5 \mathrm{mg} / \mathrm{ml}$ matrine; ( $\mathrm{G}$ and $\mathrm{H}), 1.0 \mathrm{mg} / \mathrm{ml}$ matrine; ( $\mathrm{I}$ and $\mathrm{J}), 2.0 \mathrm{mg} / \mathrm{ml}$ matrine.

necrosis rate in $2.0 \mathrm{mg} / \mathrm{ml}$ matrine group sharply increased from 4.36 to $48.80 \%$, which may be due to the direct cytotoxic effect of $2.0 \mathrm{mg} / \mathrm{ml}$ matrine on SGC-7901 cells. Furthermore, the number of the late apoptotic/necrotic cells increased with the increase of concentration of matrine.

Observation of vacuolization in cytoplasm by inverted phase contrast microscopy. Inverted phase contrast microscopy was conducted to observe the morphological characteristics of SGC-7901 cells. As shown in Fig. 5, control cells not treated with matrine were well adhered, showing normal morphology of SGC-7901 cells, while the cells treated with matrine for $24 \mathrm{~h}$ displayed abundant cytoplasmic vacuoles of varying sizes. Vacuolization in cytoplasm progressively became larger and denser when the concentration of matrine was increased. Moreover, the majority of cells treated with matrine at the concentration of $1.0 \mathrm{mg} / \mathrm{ml}$ became round and shrunken, especially in $2.0 \mathrm{mg} / \mathrm{ml}$ matrine group, and could not be affixed to the wall or suspended in culture medium.

Autophagy detected by transmission electron microscopy. To further clarify whether the cell vacuolization induced by matrine is involved in autophagy, transmission electron microscopy (TEM) was performed to detect the cells treated with $1 \mathrm{mg} / \mathrm{ml}$ of matrine. As shown in Fig. 6, the SGC-7901 cells not treated with matrine exhibited normal ultrastructural morphology of cytoplasm, organelles and nuclei. Matrine treatment resulted in the formation of abundant autophagic vacuoles sequestrating cytoplasm and organelles, such as mitochondria and endoplasmic reticulum. Giant autophagic vacuoles filled with degraded organelles and autophagosomes were frequently observed. TEM, the standard method to detect autophagy (41), demonstrated that matrine could induce SGC-7901 cells to generate autophagy, which was consistent with the vacuolization obtained by inverted phase contrast microscopy.

MDC accumulation increases in SGC-7901 cells after matrine treatment. It has been reported that MDC is a specific marker for autophagic vacuoles (42). When the cells were viewed under a fluorescence microscope, MDC-labeled autophagic vacuoles appeared as distinct dot-like structures distributing in cytoplasm or in perinuclear regions. The matrine-treated group showed higher fluorescent density and more MDC-labeled particles in SGC-7901 cells compared with the control group (Fig. 7), indicating that matrine induced the formation of the MDC-labeled vacuoles.

Matrine up-regulated $m R N A$ expression of Beclin 1 and Bax in SGC-7901 cells. Based on the results above, matrine could induce SGC-7901 cell death through both apoptotic and autophagic pathways simultaneously. To obtain better insight into the molecular mechanism underlying the autophagy and apoptosis induced by matrine, the mRNA expression level of Beclin 1 gene which plays a key role in autophagy and Bax gene, an apoptosis-related molecule, in SGC-7901 cells treated with matrine were measured by real-time quantitative RT-PCR. As shown in Fig. 8A, matrine up-regulated the Beclin 1 mRNA expression in a dose-dependent manner. Compared to control cells untreated with matrine, the Beclin $1 \mathrm{mRNA}$ expression level increased to $11.46 \pm 0.91$ and $18.31 \pm 1.08$, respectively, when the cells were treated with matrine at the concentration of 1.0 and $2.0 \mathrm{mg} / \mathrm{ml}$. In parallel, matrine up-regulated the Bax mRNA expression in SGC-7901 cells in a dose-dependent manner (Fig. 8B). In other words, the Bax mRNA expression level steadily increased with the increasing drug concentration. 

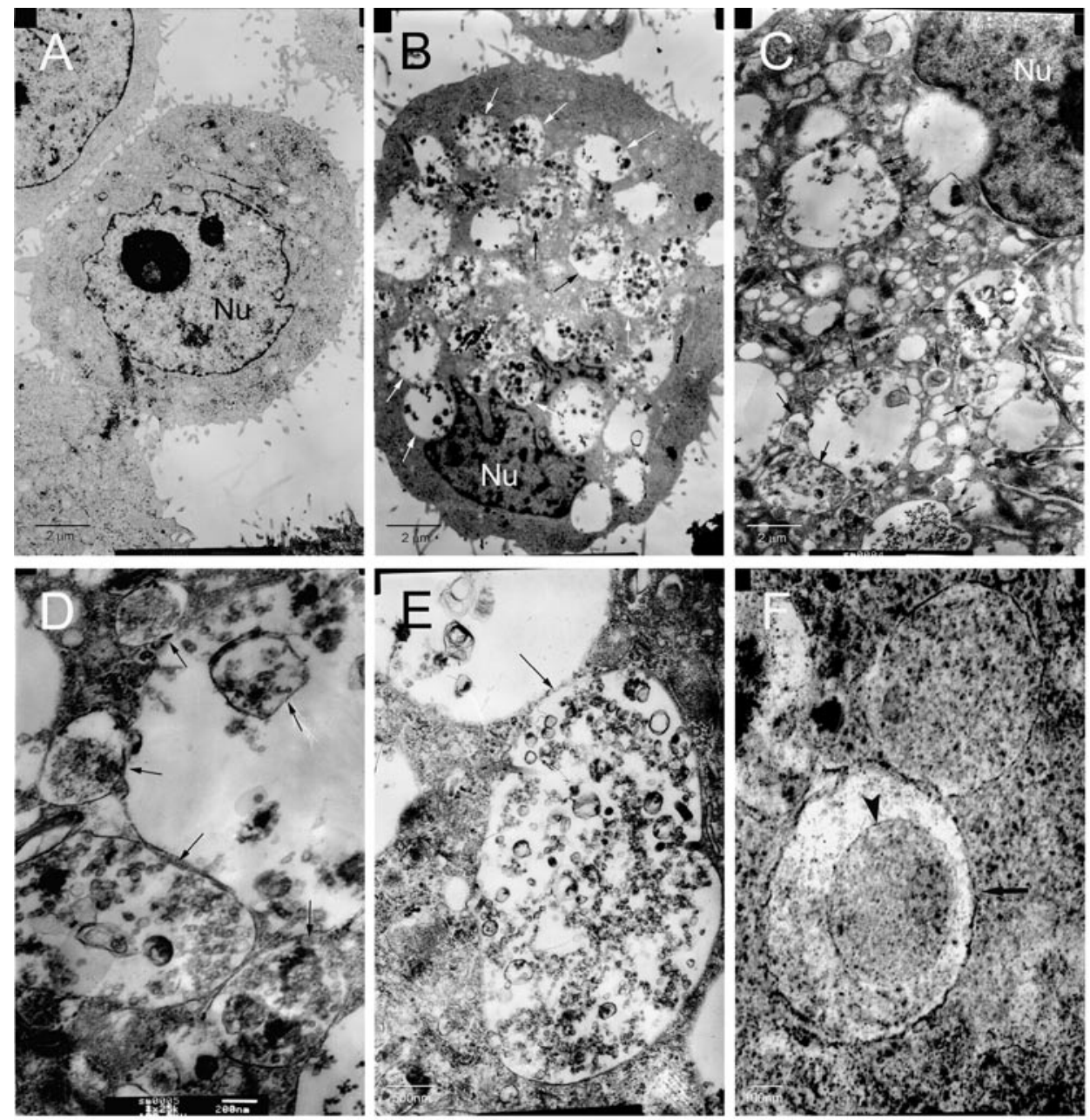

Figure 6. Ultrastructural observations in SGC-7901 cells by transmission electron microscope. (A) Untreated SGC-7901 cells exhibited normal morphology of cytoplasm, cell organelles, and nuclei. Matrine-treated SGC-7901 cells showed the characteristic ultrastructural morphology of autophagy: (B, C and D) a large number of autophagic vacuoles, (E) a giant autophagic vacuole filled with abundant degraded organelles, (F) an autophagosome sequestrating a mitochondrion and portions of cytoplasm. (A and B, $\times 4000 ; \mathrm{C}, \times 8000 ; \mathrm{D}, \times 25000 ; \mathrm{E}, \times 15000 ; \mathrm{F}, \times 50000$ ). Thin arrows represent autophagic vacuoles; thick arrows represent autophagosomes; arrowheads represent mitochondria. $\mathrm{Nu}$, nucleus.
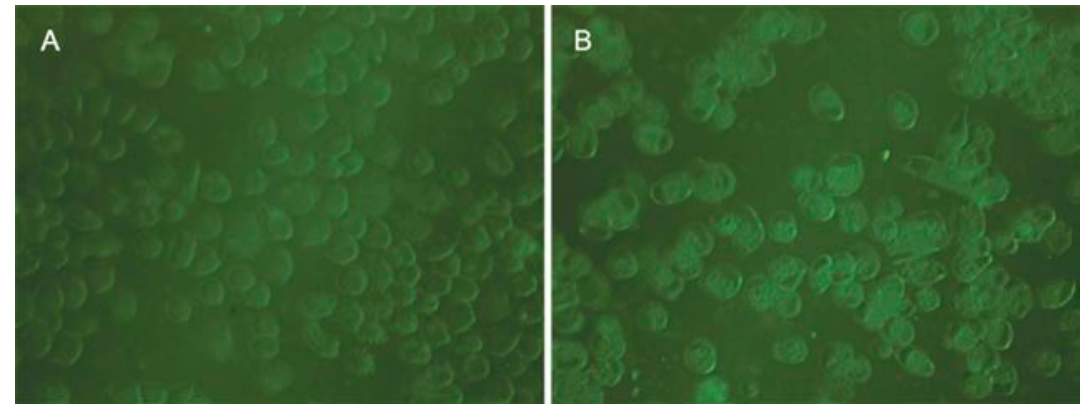

Figure 7. Visualization of MDC-labeled vacuoles in SGC-7901 cells. Autophagic vacuoles were labeled with $0.05 \mathrm{mM} \mathrm{MDC}$ in $\mathrm{PBS}$ at $37^{\circ} \mathrm{C}$ for $10 \mathrm{~min}$. Compared with the control group, the matrine-treated group showed higher fluorescent density and more MDC-labeled particles in SGC-7901 cells ( $\times 400$ magnifications). (A) $0 \mathrm{mg} / \mathrm{ml}$ matrine; (B) $1.0 \mathrm{mg} / \mathrm{ml}$ matrine.

\section{Discussion}

In this study, we observed abundant cytoplasmic vacuoles in matrine-treated SGC-7901 cells under an inverted phase contrast microscope (Fig. 5). TEM revealed the morphological changes that are typical of autophagy such as autophagosomes (Fig. 6). MDC staining obtained independent evidence supporting the conclusion that matrine triggers autophagy (Fig. 7). All these results demonstrated that autophagy is involved in antitumor effects of matrine on human gastric cancer SGC-7901 cells. In line with our data, matrine-induced autophagy in rat C6 glioma cells has been reported (26). Autophagy is an intracellular lysosomal degradation process ubiquitous in eukaryotes from yeast to mammals. Basal levels 

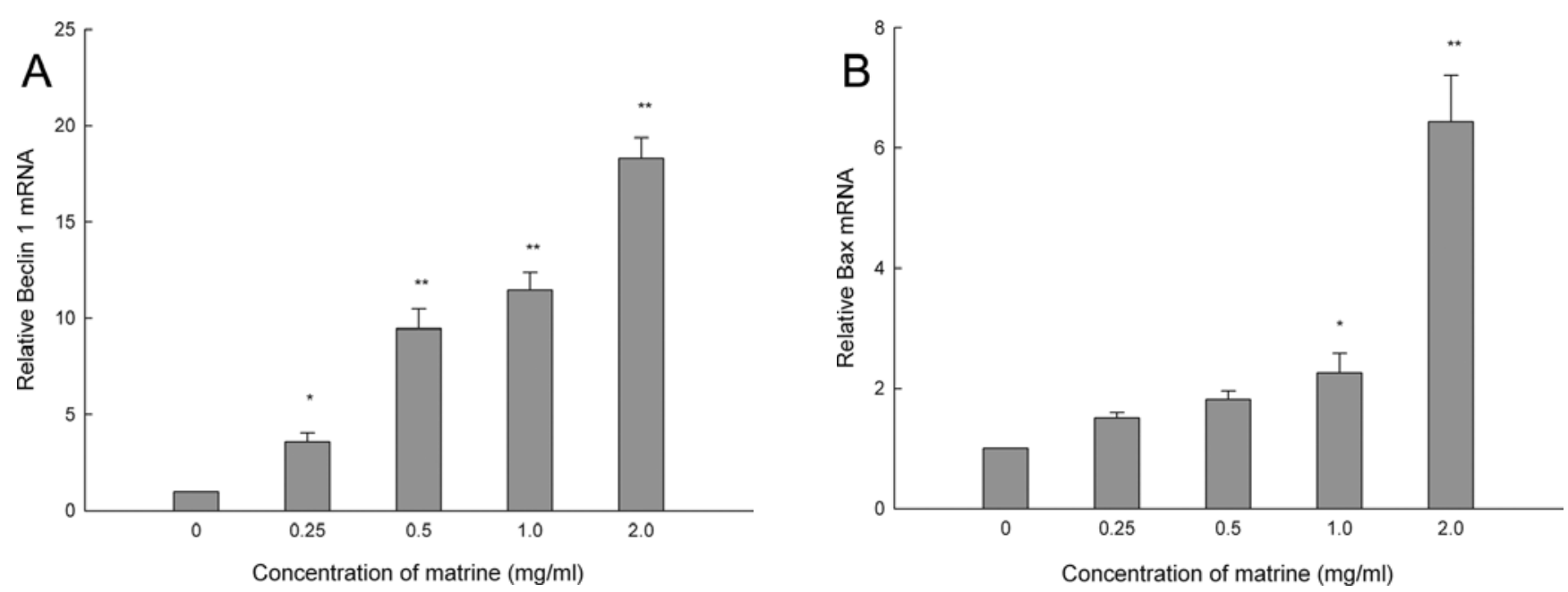

Figure 8. Matrine up-regulates mRNA levels of Beclin 1 (A) and Bax (B) in SGC-7901 cells by real-time quantitative RT-PCR. Data are shown as the mean $\pm \mathrm{SD}$ of three independent experiments. ${ }^{*} \mathrm{P}<0.01,{ }^{* *} \mathrm{P}<0.001$ compared with control group.

of autophagy are likely important in maintaining cellular homeostasis through the turnover and elimination of defective or superfluous proteins and damaged or aged organelles such as mitochondria (43). However, extensive autophagy or inappropriate activation of autophagy results in autophagic cell death (type II PCD), which is an important cell death process besides apoptosis. Autophagy is closely associated with tumors and may function as a tumor suppressor mechanism, particularly during the early stages of tumor initiation $(34,44)$. Recently, accumulating evidence has demonstrated that various anticancer therapies induce autophagy in different cancer cells, such as tamoxifen $(45,46)$, arsenic trioxide $(47)$, resveratrol (48), vitamin D analogue (49), rapamycin (50), Eupalinin A (51). Furthermore, autophagic cell death can be activated in cancer cell lines in response to these agents. During clinical cancer therapy, some tumor cells are resistant to drugs due to the failure of the cells to undergo apoptosis. Autophagic cell death compensates for apoptosis in some cell types where crucial apoptosis regulators are either lacking or inhibited. Therefore, inducing autophagy are possible strategies that can be applied to cancer therapy. In the present study, the extent of autophagy increases in a dose-dependent manner (Fig. 5), which is consistent with the dose-response antitumor effects of matrine (Fig. 2). The ability of matrine to induce autophagy underlines its potential utility as a new cancer treatment modality, especially it may provide leverage to treat cancer that is chemoresistant on the basis of ineffective apoptosis. Moreover, in order to kill gastric cancer cells very efficiently, we could use matrine in combination with inhibitors of the class I phosphatidylinositol 3-kinase $(\mathrm{PI} 3 \mathrm{~K}) /$ protein kinase $\mathrm{B}(\mathrm{Akt} / \mathrm{PKB}) /$ target of rapamycin (TOR) pathway (which are inhibitory signals of autophagy) or another anticancer drug known to induce autophagy to increase autophagic cell death.

We further investigated the mRNA expression level of Beclin 1 in SGC-7901 cells. Beclin 1, a mammalian orthologue of the yeast $\operatorname{Atg} 6 / \operatorname{Vps} 30$ gene, is the first identified mammalian gene to induce autophagy (34). Beclin 1 functions in autophagy as part of class III phosphatidylinositol 3-kinase
(PI3K) complex, which is essential for the initiation of the early stages of autophagy. Beclin 1 is monoallelically deleted in up to $75 \%$ of ovarian cancers, $50 \%$ of breast cancers, and $40 \%$ of prostate cancers (52). Beclin 1 expression is frequently decreased or absent in various cancer cells, such as human breast carcinoma, ovarian cancer, brain tumors, cervical cell carcinoma, and gastric cancer (34,52-55). Targeted mutant mice with heterozygous disruption of Beclin 1 increase the frequency of spontaneous tumors including lymphomas, lung carcinomas, hepatocellular carcinomas $(35,56)$. Beclin $1^{-1-}$ homozygous embryonic stem cells exhibit a decreased number of autophagic vesicles (56). Ectopic expression of Beclin 1 restores full autophagy potential in Beclin 1 deficient MCF-7 cells (34). These findings demonstrate that Beclin 1 is a critical component of mammalian autophagy and a haplo-insufficient tumor suppressor. In our study, matrine treatment increased the expression of Beclin 1 in SGC-7901 cells in a dose-dependent manner (Fig. 8A), indicating that Beclin 1 is involved in matrine-induced autophagy and plays an important role in matrine-mediated anti-cancer activities.

In this research, matrine obviously inhibited the growth of SGC-7901 cells in a dose- and time-dependent manner (Fig. 2), which is consistent with reported findings (57-59). Previous studies demonstrated that Beclin 1 gene transfer decreased the rates of cell proliferation in human breast carcinoma cells and colon cancer cells $(34,60)$, and Beclin 1 heterozygous disruption results in increased cellular proliferation (35). Accordingly, antiproliferation effect of matrine was associated with an increase in the expression of Beclin 1 induced by matrine. In addition, flow cytometry showed that matrine blocked SGC-7901 cells in G0/G1 phase of cell cycle (Fig. 3), suggesting that retardation of cell cycle progression may be one of the mechanisms underlying the antiproliferative effect of matrine.

Both apoptosis and autophagy are vital biological processes in cells. Evidence indicates that Bax, a pro-apoptotic protein, promotes apoptosis by influencing the permeability of the mitochondrial outer membrane and facilitating the release of 
cytochrome c (61). In this study, matrine induced apoptosis of SGC-7901 cells in a dose-dependent manner (Fig. 4), concomitant with the up-regulation of the mRNA expression of Bax in a dose-dependent manner (Fig. 8B), indicating that the pro-apoptotic mechanisms of matrine may be related to its effects on increasing the pro-apoptotic Bax expression. Similar results were observed in previous study that matrine induced MKN45 cell apoptosis via up-regulating the proapoptotic molecules Bax, Bak and Bim (23).

In conclusion, matrine has potent antitumor activities in gastric cancer SGC-7901 cells. Apart from its effect of antiproliferation, both autophagy and apoptosis were activated when death of SGC-7901 cells occurred after matrine treatment. Autophagy induced by matrine may have important therapeutic implications, especially it may provide leverage to treat gastric cancer that is chemoresistant on the basis of ineffective apoptosis. The increased Bax expression may trigger matrine-induced apoptosis of SGC-7901 cells and Beclin 1 is involved in matrine-induced autophagy. However, the relationship between autophagy and apoptosis is quite complicated, and has not been well elucidated, especially in cancer cells. The molecular mechanism underlying autophagy and apoptosis induced by matrine should be further explored.

\section{Acknowledgements}

This study was supported by the National Natural Science Foundation of China (Grant No. 30870364) and the Science and Technology Support Program of Gansu Province, China (Grant No. 0708NKCA129).

\section{References}

1. Parkin DM, Bray F, Ferlay J and Pisani P: Global cancer statistics, 2002. CA Cancer J Clin 55: 74-108, 2005.

2. Yang L: Incidence and mortality of gastric cancer in China World J Gastroenterol 12: 17-20, 2006.

3. Forman D and Burley VJ: Gastric cancer: global pattern of the disease and an overview of environmental risk factors. Best Pract Res Clin Gastroenterol 20: 633-649, 2006.

4. Brenner H, Rothenbacher D and Arndt V: Epidemiology of stomach cancer. Methods Mol Biol 472: 467-477, 2009.

5. Gravalos C and Jimeno A: HER2 in gastric cancer: a new prognostic factor and a novel therapeutic target. Ann Oncol 19: 1523-1529, 2008.

6. Cheng H, Xia B, Zhang L, et al: Matrine improves 2,4,6-trinitrobenzene sulfonic acid-induced colitis in mice. Pharmacol Res 53: 202-208, 2006.

7. Hu ZL, Zhang JP, Qian DH, et al: Effects of matrine on mouse splenocyte proliferation and release of interleukin-1 and -6 from peritoneal macrophages in vitro. Zhongguo Yao Li Xue Bao 17: 259-261, 1996.

8. Liu JY, Hu JH, Zhu QG, Li FQ, Wang J and Sun HJ: Effect of matrine on the expression of substance $P$ receptor and inflammatory cytokines production in human skin keratinocytes and fibroblasts. Int Immunopharmacol 7: 816-823, 2007.

9. Suo Z, Liu Y, Ferreri M, et al: Impact of matrine on inflammation related factors in rat intestinal microvascular endothelial cells. J Ethnopharmacol 125: 404-409, 2009.

10. Li CQ, Zhu YT, Zhang FX, et al: Anti-HBV effect of liposomeencapsulated matrine in vitro and in vivo. World $\mathrm{J}$ Gastroenterol 11: 426-428, 2005

11. Long Y, Lin XT, Zeng KL and Zhang L: Efficacy of intramuscular matrine in the treatment of chronic hepatitis $B$ Hepatobiliary Pancreat Dis Int 3: 69-72, 2004.

12. Liu J, Zhu M, Shi R and Yang M: Radix Sophorae flavescentis for chronic hepatitis B: a systematic review of randomized trials. Am J Chin Med 31: 337-354, 2003.
13. Zhang JP, Zhang M, Zhou JP, et al: Antifibrotic effects of matrine on in vitro and in vivo models of liver fibrosis in rats. Acta Pharmacol Sin 22: 183-186, 2001.

14. Zhang JP, Zhang M, Jin C, et al: Matrine inhibits production and actions of fibrogenic cytokines released by mouse peritoneal macrophages. Acta Pharmacol Sin 22: 765-768, 2001.

15. Yin LL and Zhu XZ: The involvement of central cholinergic system in (+)-matrine-induced antinociception in mice. Pharmacol Biochem Behav 80: 419-425, 2005.

16. Li X, Chu W, Liu J, et al: Antiarrhythmic properties of long-term treatment with matrine in arrhythmic rat induced by coronary ligation. Biol Pharm Bull 32: 1521-1526, 2009.

17. Zhang BH, Wang NS, Li XJ, Kong XJ and Cai YL: [Antiarrhythmic effects of matrine]. Zhongguo Yao Li Xue Bao 11: 253-257, 1990

18. Zhou Y, Shan H, Qiao G, Sui X, Lu Y and Yang B: Inotropic effects and mechanisms of matrine, a main alkaloid from Sophora flavescens AIT. Biol Pharm Bull 31: 2057-2062, 2008.

19. Wan XY, Luo M, Li XD and He P: Hepatoprotective and antihepatocarcinogenic effects of glycyrrhizin and matrine. Chem Biol Interact 181: 15-19, 2009.

20. Zhang LP, Jiang JK, Tam JW, et al: Effects of Matrine on proliferation and differentiation in K-562 cells. Leuk Res 25: 793-800, 2001.

21. Hu MJ, Zeng H, Wu YL, et al: Synergistic effects of matrine and 5 -fluorouracil on tumor growth of the implanted gastric cancer in nude mice. Chin J Dig Dis 6: 68-71, 2005.

22. Zhang Y, Zhang H, Yu P, et al: Effects of matrine against the growth of human lung cancer and hepatoma cells as well as lung cancer cell migration. Cytotechnology 59: 191-200, 2009.

23. Luo C, Zhu Y, Jiang T, et al: Matrine induced gastric cancer MKN45 cells apoptosis via increasing pro-apoptotic molecules of Bcl-2 family. Toxicology 229: 245-252, 2007.

24. Yu P, Liu Q, Liu K, Yagasaki K, Wu E and Zhang G: Matrine suppresses breast cancer cell proliferation and invasion via VEGF-Akt-NF-kappaB signaling. Cytotechnology 59: 219-229, 2009.

25. Dai ZJ, Gao J, Ji ZZ, et al: Matrine induces apoptosis in gastric carcinoma cells via alteration of Fas/FasL and activation of caspase-3. J Ethnopharmacol 123: 91-96, 2009.

26. Zhang S, Qi J, Sun L, et al: Matrine induces programmed cell death and regulates expression of relevant genes based on PCR array analysis in C6 glioma cells. Mol Biol Rep 36: 791-799, 2009 .

27. Han Y, Zhang S, Wu J, et al: Matrine induces apoptosis of human multiple myeloma cells via activation of the mitochondrial pathway. Leuk Lymphoma 51: 1337-1346, 2010.

28. Ma L, Wen S, Zhan Y, He Y, Liu X and Jiang J: Anticancer effects of the Chinese medicine matrine on murine hepatocellular carcinoma cells. Planta Med 74: 245-251, 2008.

29. Liu XS, Jiang J, Jiao XY, Wu YE and Lin JH: Matrine-induced apoptosis in leukemia U937 cells: involvement of caspases activation and MAPK-independent pathways. Planta Med 72: 501-506, 2006

30. Jiang H, Hou C, Zhang S, et al: Matrine upregulates the cell cycle protein E2F-1 and triggers apoptosis via the mitochondrial pathway in K562 cells. Eur J Pharmacol 559: 98-108, 2007.

31. Liu XY, Fang H, Yang ZG, et al: Matrine inhibits invasiveness and metastasis of human malignant melanoma cell line A375 in vitro. Int J Dermatol 47: 448-456, 2008.

32. Zhang L, Wang T, Wen X, et al: Effect of matrine on HeLa cell adhesion and migration. Eur J Pharmacol 563: 69-76, 2007.

33. Zhang $\mathrm{Y}$, Wang S, Li Y, Xiao Z, Hu Z and Zhang J: Sophocarpine and matrine inhibit the production of TNF-alpha and IL-6 in murine macrophages and prevent cachexia-related symptoms induced by colon 26 adenocarcinoma in mice. Int Immunopharmacol 8: 1767-1772, 2008.

34. Liang XH, Jackson S, Seaman M, et al: Induction of autophagy and inhibition of tumorigenesis by beclin 1 . Nature 402: 672-676, 1999.

35. Qu X, Yu J, Bhagat G, et al: Promotion of tumorigenesis by heterozygous disruption of the beclin 1 autophagy gene. J Clin Invest 112: 1809-1820, 2003.

36. Morselli E, Galluzzi L, Kepp O, et al: Anti- and pro-tumor functions of autophagy. Biochim Biophys Acta 1793: 1524-1532, 2009.

37. Xiong HY, Guo XL, Bu XX, et al: Autophagic cell death induced by 5-FU in Bax or PUMA deficient human colon cancer cell. Cancer Lett 288: 68-74, 2010. 
38. Skehan P, Storeng R, Scudiero D, et al: New colorimetric cytotoxicity assay for anticancer-drug screening. J Natl Cancer Inst 82: 1107-1112, 1990.

39. Martin SJ, Reutelingsperger CP, McGahon AJ, et al: Early redistribution of plasma membrane phosphatidylserine is a general feature of apoptosis regardless of the initiating stimulus: inhibition by overexpression of Bcl-2 and Abl. J Exp Med 182: $1545-1556,1995$.

40. Munafo DB and Colombo MI: A novel assay to study autophagy: regulation of autophagosome vacuole size by amino acid deprivation. J Cell Sci 114: 3619-3629, 2001.

41. Mizushima N: Methods for monitoring autophagy. Int J Biochem Cell Biol 36: 2491-2502, 2004

42. Biederbick A, Kern HF and Elsasser HP: Monodansylcadaverine (MDC) is a specific in vivo marker for autophagic vacuoles. Eur J Cell Biol 66: 3-14, 1995.

43. Levine B and Kroemer G: Autophagy in the pathogenesis of disease. Cell 132: 27-42, 2008

44. Chen N and Debnath J: Autophagy and tumorigenesis. FEBS Lett 584: 1427-1435, 2010.

45. Bursch W, Ellinger A, Kienzl H, et al: Active cell death induced by the anti-estrogens tamoxifen and ICI 164384 in human mammary carcinoma cells (MCF-7) in culture: the role of autophagy. Carcinogenesis 17: 1595-1607, 1996.

46. Bursch W, Hochegger K, Torok L, Marian B, Ellinger A and Hermann RS: Autophagic and apoptotic types of programmed cell death exhibit different fates of cytoskeletal filaments. J Cell Sci 113 ( Pt 7): 1189-1198, 2000.

47. Kanzawa T, Zhang L, Xiao L, Germano IM, Kondo Y and Kondo S: Arsenic trioxide induces autophagic cell death in malignant glioma cells by upregulation of mitochondrial cell death protein BNIP3. Oncogene 24: 980-991, 2005.

48. Opipari AW Jr, Tan L, Boitano AE, Sorenson DR, Aurora A and Liu JR: Resveratrol-induced autophagocytosis in ovarian cancer cells. Cancer Res 64: 696-703, 2004

49. Hoyer-Hansen M, Bastholm L, Mathiasen IS, Elling F and Jaattela M: Vitamin D analog EB1089 triggers dramatic lysosomal changes and Beclin 1-mediated autophagic cell death. Cell Death Differ 12: 1297-1309, 2005.
50. Takeuchi H, Kondo Y, Fujiwara K, et al: Synergistic augmentation of rapamycin-induced autophagy in malignant glioma cells by phosphatidylinositol 3-kinase/protein kinase B inhibitors. Cancer Res 65: 3336-3346, 2005.

51. Itoh $\mathrm{T}$, Ito $\mathrm{Y}$, Ohguchi $\mathrm{K}$, et al: Eupalinin $\mathrm{A}$ isolated from Eupatorium chinense L. induces autophagocytosis in human leukemia HL60 cells. Bioorg Med Chem 16: 721-731, 2008.

52. Aita VM, Liang XH, Murty VV, et al: Cloning and genomic organization of beclin 1, a candidate tumor suppressor gene on chromosome 17q21. Genomics 59: 59-65, 1999.

53. Miracco C, Cosci E, Oliveri G, et al: Protein and mRNA expression of autophagy gene Beclin 1 in human brain tumours. Int J Oncol 30: 429-436, 2007.

54. Wang ZH, Xu L, Duan ZL, Zeng LQ, Yan NH and Peng ZL: Beclin 1-mediated macroautophagy involves regulation of caspase-9 expression in cervical cancer HeLa cells. Gynecol Oncol 107: 107-113, 2007.

55. Furuya D, Tsuji N, Yagihashi A and Watanabe N: Beclin 1 augmented cis-diamminedichloroplatinum induced apoptosis via enhancing caspase-9 activity. Exp Cell Res 307: 26-40, 2005.

56. Yue Z, Jin S, Yang C, Levine AJ and Heintz N: Beclin 1, an autophagy gene essential for early embryonic development, is a haploinsufficient tumor suppressor. Proc Natl Acad Sci USA 100: 15077-15082, 2003.

57. Li H, Tan G, Jiang X, et al: Therapeutic effects of matrine on primary and metastatic breast cancer. Am J Chin Med 38: 1115-1130, 2010.

58. Liu T, Song Y, Chen H, Pan S and Sun X: Matrine inhibits proliferation and induces apoptosis of pancreatic cancer cells in vitro and in vivo. Biol Pharm Bull 33: 1740-1745, 2010.

59. Qin XG, Hua Z, Shuang W, Wang YH and Cui YD: Effects of matrine on HepG2 cell proliferation and expression of tumor relevant proteins in vitro. Pharm Biol 48: 275-281, 2010.

60. Koneri K, Goi T, Hirono Y, Katayama K and Yamaguchi A: Beclin 1 gene inhibits tumor growth in colon cancer cell lines. Anticancer Res 27: 1453-1457, 2007.

61. Sheridan C, Delivani P, Cullen SP and Martin SJ: Bax- or Bak-induced mitochondrial fission can be uncoupled from cytochrome C release. Mol Cell 31: 570-585, 2008. 